\title{
UNIFORM COMMERCIAL CODE: VARIATION BETWEEN OFFER AND ACCEPTANCE UNDER SECTION 2-207
}

$A_{\mathrm{r}}$ acceptance conforming to the terms of the offer. ${ }^{1}$ Any variance in the terms of the acceptance is considered a rejection of the offer and a counteroffer which must be accepted by the original offeror before a valid contract arises. ${ }^{2}$

Section $2-207(x)$ of the Uniform Commercial Code ${ }^{3}$ (UCC) relaxes these rigid rules in order to give binding effect to expressions of acceptance even though they include terms varying from those of the offer, "unless acceptance is expressly made conditional on assent to the additional or different terms." Additional terms in the acceptance are regarded by section 2-207(2) as proposals for additions to the contract, except that "between merchants such terms become part of the contract unless ... they materially alter it ...." Th The drafters of the UCC indi-

\footnotetext{
${ }^{1}$ See I Corbin, Contracts $\$ \$ 82,83$ (1950); 77 C.J.S. Sales $\$ 29$ (1952); I Williston, Contracts $\$ \$$ 72, 73 (3d ed. I957); Restatement, Contracts $\$ 59$ (1932).

${ }^{2}$ See I CoRrin, op. cit. supra note $1 ; 77$ C.J.S., op. cit. supra note 1 ; I Williston, Contracts $\$ \$ 73,77$ (3d ed. 1957); RESTATEMENT, CONTRACTS $\$ 60$ (1932).

Immaterial variances, however, may have no effect. See Newspaper Readers Service, Inc. v. Cannonsburg Pottery Co., 146 F.2d 963 (3d Cir. 1945); Valashiuas v. Koniuto, 308 N.Y. 233, 124 N.E.2d 300 (1954). Precatory language or suggestions as to mode of performance will not prevent an effective acceptance. See Skinner v. Stone, 144 Ark. 353, 222 S.W. 360 (1920); Butler v. Foley, 2 I I Mich. 668, I79 N.W. 34 (1920); Rucker v. Saunders, I82 N.C. 607, 109 S.E. 857 (1921).

References to the UNIFORM COMMERcial CODE [hereinafter cited as UCC] are to the 1957 Official Text with Comments.

The complete text of $\$ 2-207$ is as follows:

"( 1 ) A definite and seasonable expression of acceptance or a written confirmation which is sent within a reasonable time operates as an acceptance even though it states terms additional to or different from those offered or agreed upon, unless acceptance is expressly made conditional on assent to the additional or different terms.

(2) The additional terms are to be construed as proposals for addition to the contract. Between merchants such terms become part of the contract unless:

(a) the offer expressly limits acceptance to the terms of the offer;

(b) they materially alter it; or

(c) notification of objection to them has already been given or is given within a reasonable time after notice of them is received.

(3) Conduct by both parties which recognizes the existence of a contract is sufficient to establish a contract for sale although the writings of the parties do not otherwise establish a contract. In such case the terms of the particular contract consist
} 
cated that this section was intended to be applicable in two typical situations where the common law prevented formation of a contract: ( $I$ ) where there is a prior oral or informal agreement followed by a confirmation including terms materially altering the agreement, and (2) where a writing intended as a closing or confirmation of an agreement includes further minor suggestions."

In the recent case of Roto-Lith, Ltd. v. F. P. Bartlett E Co., ${ }^{\circ}$ the United States Court of Appeals for the First Circuit interpreted section 2-207 in still another context. Plaintiff, a manufacturer of cellophane bags for packaging vegetables, mailed the defendant a written order for adhesive emulsion which the latter produced for use on cellophane. ${ }^{7}$ The defendant sent the plaintiff an acknowledgment which included provisions excluding all warranties and which required the buyer to notify the defendant immediately if those terms were not "acceptable." The goods were shipped the following day." Plaintiff, without objecting to defendant's attempt to limit its liability, used the emulsion which, plaintiff contended, failed to adhere properly. Thus, in the present case, there was neither the prior informal agreement nor the insignificant variances contemplated by the drafters of section 2-207.

The district court, at the close of all the evidence, directed a verdict for the defendant. On appeal, plaintiff claimed that under section

of those terms on which the writings of the parties agree, together with any supplementary terms incorporated under any provisions of this Act."

" "This section is intended to deal with two typical situations. The one is where an agreement has been reached either orally or by informal correspondence between the parties and is followed by one or both of the parties sending formal acknowledgments or inemoranda embodying the terms so far as agreed upon and adding terms not discussed. The other situation is one in which a wire or letter expressed and intended as the closing or confirmation of an agreement adds further minor suggestions or proposals such as 'ship by Tuesday,' 'rush,' 'ship draft against bill of lading inspection allowed,' or the like." UCC § 2-207, Comment I.

297 F.2d 497 (1st Cir. 1962).

The case concerned two sales of adhesive emulsion-one in May and one in October of 1959. The appeal as to the May transaction was disposed of on procedural grounds. Id. at 500-01. Only the October transaction was decided on the merits, and it is, therefore, the one discussed in this note.

${ }^{8}$ The acknowledgment stated conspicuously on its face: "All goods sold without warranties, express or implied, and subject to the terms on reverse side." " On the back was a further disclaimer of " '. . . any and all warranties, guarantees, or representations whatsoever," " as well as a provision stating: "'This acknowledgment contains all of the terms of this purchase and sale .... If these terms are not acceptable, Buyer must so notify Seller at once." "297 F.2d at 498-99.

- Although there was no direct testimony, the plaintiff was found to have received the acknowledgment no later than the goods. Id. at 498 . 
$2-207^{10}$ a binding contract was formed on the terms of its order. Plaintiff contended that defendant's disclaimer was an additional term materially altering the agreement and, therefore, was not part of the contract, but merely a proposal by defendant for an addition to the contract to which the plaintiff did not assent. ${ }^{11}$ The First Circuit, although agreeing that the disclaimer of warranties materially altered the agreement, ${ }^{12}$ concluded that defendant's acceptance was "expressly" conditioned on the plantiff's assent to the new terms in defendant's acknowledgment and affirmed the lower court's decision. ${ }^{13}$ In effect, therefore, no contract was formed until the plaintiff assented to the conditions by accepting and using the emulsion with knowledge ${ }^{14}$ of the disclaimer provisions. ${ }^{15}$

Section $2-207$ (2) regards material alterations contained in the acceptance as mere proposals for additions to an already existing con-

${ }^{20}$ The court applied Massachusetts law. Id. at 499. Massachusetts had adopted the present text of UCC § 2-207 without revision. MAss. ANN. LAws ch. 106, § 2-207 (Supp. 1958).

${ }_{21}$ By the terms of $\S 2-207(2)$, the offeror need not expressly reject material alterations to prevent their incorporation into the contract. If there already is a binding contract, the offeror's performance is expected and, therefore, will not normally give rise to an implied agreement to the alterations. On the contrary, if the proposed changes are important ones, it is reasouable to assume that the offeror does not consent to their inclusion in the contract. Express assent, therefore, is required for their incorporation. See UCC $\S 2-207$, Comment 3 . If there is no contract because the acceptance was expressly conditional, see note 15 infra.

${ }_{22} 297$ F.2d at 499 . Comment 4 to UCC $\S 2-207$ specifically refers to a disclaimer of standard warranties as a clause which would materially alter the contract. It indicates that the test of materiality is whether or not inclusion of the clause would result in surprise or hardship to the other party if he were not expressly aware of it.

The Comments, which explain the purposes of the various provisions of the UCC, were added "to promote uniformity, to aid in viewing the Act as an integrated whole, and to safeguard against misconstruction." UCC, I957 OFFICIAL TEXT I. Although the Comments were not enacted into law in Massachusetts, they are annexed to the Annotated Laws of Massachusetts and were referred to by the First Circuit as support for its finding.

${ }^{13} 297$ F.2d at 500 .

"See note 9 supra.

${ }^{15} 297$ F.2d at 500 . By the court's reasoning, the acknowledgment constituted a counteroffer followed by shipment of the goods. Acceptance of goods or services offered may create a binding contract. See Champlin v. Jackson, 317 Mass. 46I, 58 N.E.2d 757 (1945); UCC § 2-204; I CoRBIN, CoNTRACTS § 75 (1950); I WILlISTON, Contracts § $91 \mathrm{D}$ (3d ed. 1957 ); Restatement, Contracts § 72 (1932). Therefore, plaintiff's acceptance of the emulsion formed a binding contract on the basis of the defendant's counteroffer. The plaintiff did not have to agree expressly to the disclaimer, for it was one of the terms of the counteroffer and resulting contract: 
tract, ${ }^{16}$ which do not become part of the contract "unless expressly agreed to by the other party. $m$ If the offeror does not assent to inclusion of the new terms, the offeree remains bound to a contract with which he is dissatisfied. The offeree can protect himself against being bound on terms other than his own only by making his acceptance "expressly" conditional on the offeror's assent to his proposals. ${ }^{18}$ Thus, as is seen here, the interpretation of the word "expressly" can be crucial.

Normally, the word "expressly" denotes an explicit, unequivocal statement. ${ }^{19}$ However, such a literal interpretation would be unrealistic in the context of a statute dealing with the formative stages of commercial agreements. Businessmen often use inexplicit, though reasonably understandable, language in their negotiations. If the statute were construed literally, an unwary offeree who failed to recite the required legal formula would be held to a contract on terms which he never intended to accept, for an offeree usually will not accept an offer unconditionally while proposing important changes in the resulting obligation. As the Court of Appeals pointed out, ${ }^{20}$ it would be very unrealistic to assume that an offeree who adds new terms unilaterally burdensome on the offeror intends to accept the offer unconditionally and to depend solely on the generosity of the offeror to assume the new restrictions. The offeror could hardly be expected to adopt such burdensome provisions if he could have an enforceable contract on his own terms by simply ignoring or expressly rejecting the new proposals. The First Circuit prevented that unfortunate result by holding that "a response which states a condition materially altering the obligation solely to the disadvantage of the offeror is an 'acceptance ... expressly ... conditional on assent to the additional . . . terms, ${ }^{\prime 21}$ and thus a rejection and counteroffer.

Sound justification for the First Circuit Court of Appeal's liberal construction of seemingly clear statutory language can be found within the UCC itself. Section I-IO2(I) provides that the code "shall be liberally construed and applied to promote its underlying purposes and policies," which include clarification of the commercial law and "con-

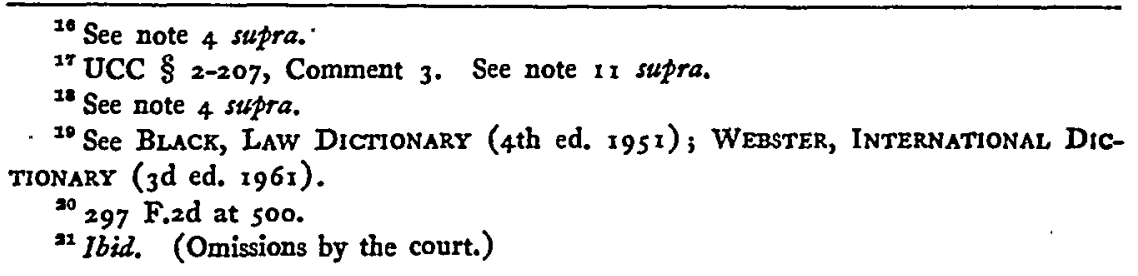


tinued expansion of commercial practices through custom [and] usage." Comment $\mathrm{I}$ to section $\mathrm{I}-\mathrm{IO} 2$ indicates that each section should be interpreted so as to effectuate its particular purposes and policies. ${ }^{22}$ The provisions of section 2-207 manifest a purpose to recognize the existence of a binding contract which previously would have been thwarted by the strict common law rules of offer and acceptance but which the parties would reasonably understand to exist. ${ }^{23}$ The First Circuit's interpretation would appear to be consistent with the section's purpose.

The effect of the decision in the Roto-Lith case is merely to invoke the common law rule in a situation seemingly overlooked by the drafters of the UCC. ${ }^{24}$ While putting no novel burden on the offeror, the First Circuit's interpretation serves to keep negotiations open until full accord has been reached on the important terms of the contract. Pending revision of section $2-207$ to cover more explicitly the situation presented in Roto-Lith, ${ }^{25}$ the interpretation adopted by the First Circuit Court of Appeals commends itself to other UCC jurisdictions as an equitable recognition of reasonable commercial expectations.

22 "The text of each section should be read in the light of the purpose and policy of the rule or principle in question, as also of the Act as a whole, and the application of the language should be construed narrowly or broadly, as the case may be, in conformity with the purposes and policies involved." UCC \& I-I02, Comment 1 .

${ }^{23}$ See note 4 supra. See UCC $\$ 2-207(3)$ and Comment 2.

"See note 5 sippra. UCC \& 1-103 provides that the "principles of law and equity" should supplement the provisions of the UCC unless displaced by its particular provisions.

${ }^{25}$ A workable revision might be to give binding effect to an acceptance with terms varying from the offer, "unless acceptance is expressly, or by clear implication, made conditional on assent to the additional or different terms." The code would then adequately cover the situations presently contemplated by $\$ 2-207$ without being unduly harsh in situations like the Roto-Lith case.

The New York Law Revision Commission recommended that UCC $\$ 2-207$ be restricted to immaterial variances. N.Y.L. REvision COMM'N, REPORT, N.Y. LEG. Doc. No. 65371 (1956). However, the New York legislature in adopting the UCC left $\$ 2-207$ unchanged, N.Y. Sess. Laws r 962 , c. 553 (effective September 27, 1964). 